\title{
The effects of plantar-flexor static stretching on perturbation recovery in the elderly
}

\author{
Seong-gil Kim', Goonchang Yuk², Hwangbo Gak ${ }^{1 *}$ \\ From 4th Congress of the International Foot and Ankle Biomechanics (i-FAB) Community \\ Busan, Korea. 8-11 April 2014
}

\section{Background}

It is important to improve the routine ADL(activities of daily living) in the elderly and then diverse and various therapeutic interventions or exercises are applied for the therapy. Generally, to increase the efficiency of the exercise and prevent the injury, the stretching is commonly used [1]. Indeed, there are many case that the elderly complain of the difficulties to control the balance after the stretching $[2,3]$. However, previous studies about the effects of stretching after or during the stretching have focused mainly on the histological or neurological changes and there are few studies that focused on the temporary balance control in the elderly $[4,5]$. Thus, the purpose of this study was to investigate the perturbation recovery of five minutes of plantar-flexor static stretching (PSS) in the elderly.

\section{Materials and methods}

Thirty-one participants aged over 65 years performed 5 min-PSS in the form of wedge board standing. The sway length of each subject's COM (center of mass) was measured to examine the subject's static balance. It was measured for one minute in quiet standing with the eyes closed. Sway length was measured for 1 minute which was divided in three 20-second-sections before and after stretching.

\section{Results}

The result showed significant decreases in sway length before stretching between 0-20s and 21-40s, 0-20s and 41-60s separately. However, the results between 21-40s and $41-60$ s did not show any significant changes. The result showed significant decreases in sway length after stretching between 0-20s and 41-60s, 21-40s and 41-60s. However, the results between $0-20$ s and 21-40s did not show any significant changes (Table 1 ).

\section{Conclusion}

Stabilization time of sway length became stable from $21 \mathrm{~s}$ before stretching with the eyes closed, but unstable duration lasted to $40 \mathrm{~s}$ after stretching, and then sway length was started to decrease from that time(Figure 1). These results suggest that the elderly subjects temporarily experienced difficulties in maintaining balance immediately after the PSS. Therefore, to prevent falls and perform exercises in a safe way, it is recommended to allow patients to rest after performing PSS.

\section{Trial registration}

Current Controlled Trials ISCRTN73824458.

Table 1 Comparison of sway length standing before and after 5 minutes plantar-flexor static stretch.

\begin{tabular}{lllll}
\hline Condition & $\mathbf{0 - 2 0 s e c}$ & $\mathbf{2 1 - 4 0 s e c}$ & $\mathbf{4 1 - 6 0 s e c}$ & $\mathbf{p}$ \\
\hline Pre-stretch & $14.00 \pm 5.18$ & $11.90 \pm 4.05$ & $11.78 \pm 5.21$ & $0.00^{\text {ac }}$ \\
\hline Post-stretch & $15.87 \pm 6.14$ & $15.32 \pm 6.13$ & $13.75 \pm 5.41$ & $0.02^{\text {bc }}$
\end{tabular}

${ }^{*} p<.05($ Mean \pm SD)

${ }^{\mathrm{a}}=0-20 \mathrm{sec} * 21-40 \mathrm{sec}{ }^{\mathrm{b}}=21-40 \mathrm{sec} * 41-60 \mathrm{sec}{ }^{\mathrm{c}}=0-20 \mathrm{sec} * 41-60 \mathrm{sec}$

\footnotetext{
* Correspondence: hbgak@daegu.ac.kr

'Department of Physical Therapy, College of Rehabilitation Science, Daegu

University, Jilyang, Gyeongsan-si, Kyeongbuk, 712-714, Republic of Korea

Full list of author information is available at the end of the article
} 


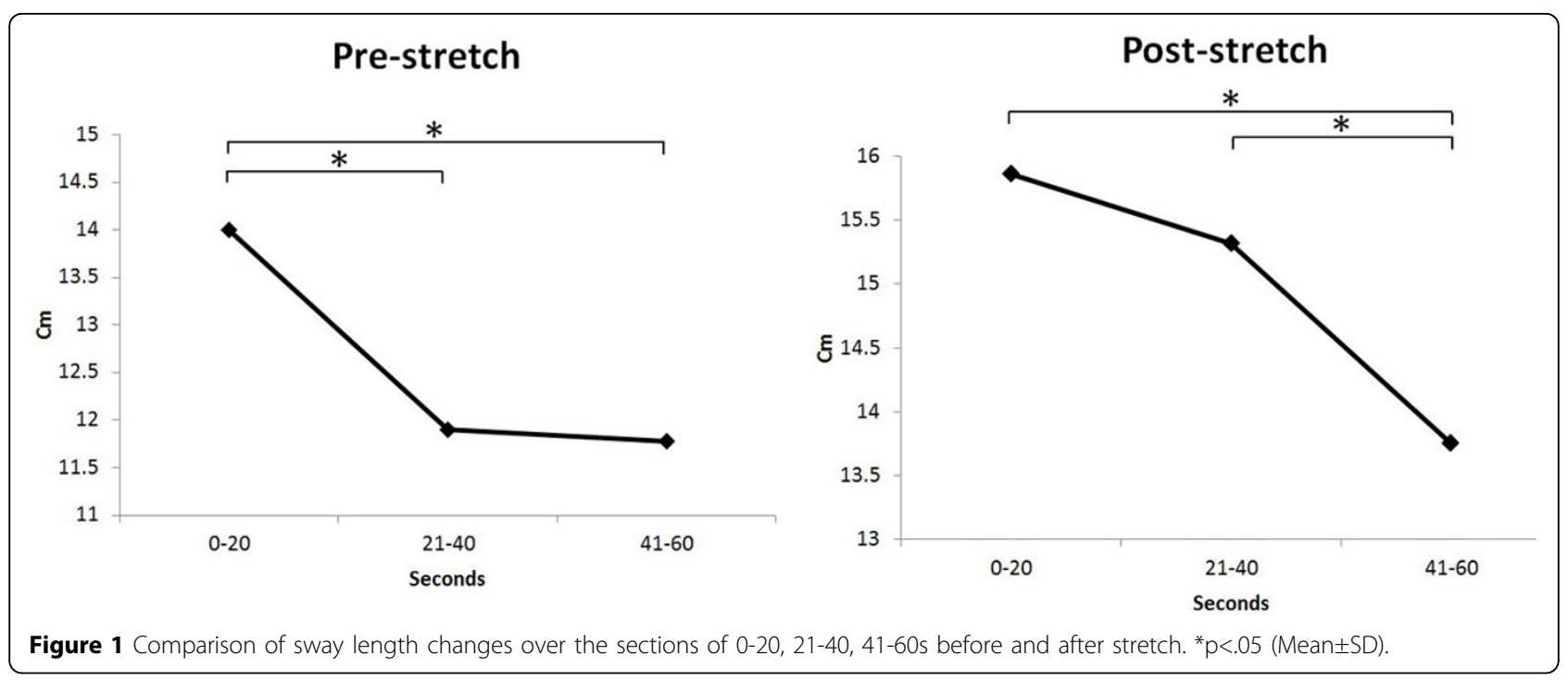

\section{Authors' details}

'Department of Physical Therapy, College of Rehabilitation Science, Daegu University, Jilyang, Gyeongsan-si, Kyeongbuk, 712-714, Republic of Korea. ${ }^{2}$ Department of Physical Therapy, Yeungnam University Hospital, 170 Hyeonchung-ro, Namgu, Daegu 705-703, Republic of Korea.

\section{Published: 8 April 2014}

\section{References}

1. Johnson G, Bradley D, Witkowski R, et al: Effect of a static calf muscletendon unit stretching program on ankle dorsiflexion range of motion of older women. Journal of geriatric physical therapy 2007, 30:49.

2. Blazevich J, Kay D, Waugh C, et al: Plantarflexor stretch training increases reciprocal inhibition measured during voluntary dorsiflexion. Journal of Neurophysiology 2012, 107:250-256.

3. Gajdosik L, Vander Linden W, McNair J, et al: Viscoelastic properties of short calf muscle-tendon units of older women: effects of slow and fast passive dorsiflexion stretches in vivo. European journal of applied physiology 2005, 95:131-139.

4. Weir E, Tingley J, Elder C: Acute passive stretching alters the mechanical properties of human plantar flexors and the optimal angle for maximal voluntary contraction. European Journal of applied physiology 2005, 93:614-623.

5. Ryan D, Herda J, Costa B, et al: Viscoelastic creep in the human skeletal muscle-tendon unit. European journal of applied physiology 2010, 108:207-211.

\section{Submit your next manuscript to BioMed Central} and take full advantage of:

- Convenient online submission

- Thorough peer review

- No space constraints or color figure charges

- Immediate publication on acceptance

- Inclusion in PubMed, CAS, Scopus and Google Scholar

- Research which is freely available for redistribution 